\title{
Advanced Glycation Endproducts: Activators of Cardiac Remodeling in Primary Fibroblasts From Adult Rat Hearts
}

\author{
Sherif Daoud ${ }^{1}$, Reinhard Schinzel ${ }^{2}$, Arne Neumann' ${ }^{2}$, Claudia Loske ${ }^{2}$, Daniela Fraccarollo ${ }^{3}$, \\ Claudius Diez ${ }^{1}$, and Andreas Simm ${ }^{1,4}$ \\ ${ }^{1}$ Institut fuer Klinische Biochemie und Pathobiochemie, Würzburg, Germany \\ ${ }^{2}$ Physiologische Chemie I, Biozentrum, Am Hubland, Würzburg, Germany \\ ${ }^{3}$ Medizinische Klinik, Würzburg, Germany \\ ${ }^{4}$ Klinik fuer Herz- und Thoraxchirurgie, Halle, Germany \\ Contributed by R. Bucala. Accepted April 20, 2001
}

\begin{abstract}
Background: Cardiovascular diseases are the leading cause of death in the Western world, especially in the elderly. Myocardial fibrosis induced by activated cardiac fibroblasts is thought to play a key role in the pathogenesis of cardiovascular disease. Accumulation of advanced glycation endproducts (AGEs), products of nonenzymatic glycation of proteins, correlate with the stiffness of the heart and large vessels. To elucidate a potential role of AGEs as a trigger of fibrosis, the effects of AGEs on primary fibroblasts from hearts of adult rats were investigated.

Material and Methods: The activation of intracellular signaling pathways was shown by Western blotting. In addition, the expression of genes of the extracellular matrix proteins, metalloproteases (MMPs), their inhibitors,
\end{abstract}

and TGF-beta were analyzed by semiquantitative PCR. Activation of MMPs were controlled by Zymography.

Results: It was shown that treatment of cardiac fibroblasts with AGEs leads to an activation of different signaling molecules, such as the p38MAP-kinase, the extracellular regulated kinases (ERKs), the jun kinase (JNK), as well as transcription factors like ATF-2 and NF- $\kappa \mathrm{B}$. In addition, the expression and activation of MMP-2, MMP-9, and MMP-13 were induced, which may be responsible for tissue remodeling followed by fibrosis.

Conclusion: Due to their effects on the expression and activation of metalloproteases, AGEs should be regarded as a potential therapeutic target for the prevention of pathologic remodeling.

\section{Introduction}

The glycation or Maillard reaction is the nonenzymatic reaction of amino acids with carbohydrates. This reaction starts with the formation of a Schiff base from the carbonyl group of a reducing sugar such as glucose and a primary amino group. The Schiff base rearranges to the Amadori product. Over time, in a series of reactions including dehydrations and especially oxidation reaction, a heterogeneous group of compounds is formed, the advanced glycation end products (AGEs), which exhibit characteristic absorbance and fluorescence properties (1).

AGEs accumulate in various tissues in the course of ageing $(2,3)$. However, a pathologic role of the nonenzymatic modification of proteins by reducing sugars has become increasingly evident. AGEs have been implicated in the development of many complications related to diabetes and ageing, such as atherosclerosis, retinopathy, and diabetic nephropathy (4-6). Although the role of AGEs in the pathogenesis of diabetic complications is supported by numerous studies, little is known about a possible pathophysiologic role

Address correspondence and reprint requests to: PD Dr. A. Simm, Klinik fuer Herz- und Thoraxchirurgie, Ernst-Grube-Str. 40, D-06120 Halle, Germany.

Phone: +49 (0) 345557 2647; fax: +49 (0) 345557 2782;

e-mail: andreas.simm@medizin.uni-halle.de of AGEs in the ageing or diseased heart. Deposition of AGEs and expression of the receptor for AGE were observed in the cardiovascular tissue of the diabetic rat $(7,8)$. Serum levels of AGEs are increased in patients with type 2 diabetes and coronary heart disease, and are associated with left ventricular diastolic function in patients with type 1 diabetes $(9,10)$. The inhibitor of AGE formation, aminoguanidine, prevents age-related arterial stiffening and cardiac hypertrophy. AGE cross-link breakers can reverse agerelated increases in myocardial stiffness $(11,12)$. Apart from hypertrophy, fibrosis is one of the hallmarks of age- and disease- related heart failure.

Although nothing is known about effects of AGEs on heart fibroblasts, which play an important role in disease related tissue-remodeling, participation of AGEs in other forms of fibrosis has been demonstrated. Renal fibrosis is one of the most important characteristics of diabetic nephropathy leading to endstage renal disease (ESRD) (13). A potential role of AGEs and glycation products in renal fibrosis has been noted and activation of a renal fibroblast cell line by AGEs has recently been shown (14-16). Induction of extracellular matrix proteins (ECM) by AGEs has been shown also for endothelial cells $(17,18)$.

In addition to direct effects such as formation of protein cross-links, AGEs can exert their effects via cell activation. Activation of many different cell 
types has been demonstrated. Incubation of endothelial cells with AGEs resulted in the activation of the transcription factor NF- $\kappa \mathrm{B}$ and up-regulation of various NF- $\kappa$ B-controlled genes (19). Studies in rat pulmonary artery smooth muscle cells have shown that AGEs are able to activate p21(ras) as well as the MAP-kinases ERK-1 and ERK-2 via a RAGE-dependent pathway (20). This result is supported by studies in the renal tubule cell line LLCPK1, where AGEs were shown to activate p42 (MAP) kinase (ERK-2) and its downstream target, the AP-1 complex (21).

In view of these observations, a potential involvement of AGEs in heart fibrosis was tested by incubation of primary fibroblasts of the adult rat heart with in vitro modified AGE albumin. The aim of this study is to (1) prove that AGEs specifically induce signal transduction pathways, especially the MAP-Kinase pathway and (2) to show the effects of AGEs on the ECM by determination of expression of ECM proteins itself, of matrix metalloproteases (MMPs), and of tissue inhibitors of metalloproteases (TIMPs) in the absence and the presence of AGEs, all of which are indicative for tissue remodeling in the heart by AGEs.

\section{Materials and Methods}

\section{Generation and Characterization of Glycated Proteins and Peptides}

Bovine serum albumin (BSA) (1 mM Fraction V, Sigma, Deisenhofen, Germany) solution was maximally glycated by incubation with $0.5 \mathrm{M}$ glucose in $\mathbf{5 0}$ mM potassium phosphate, $\mathrm{pH}$ 7.3, 1 mM EDTA under sterile conditions at $50^{\circ} \mathrm{C}$ for 40 days following a modified protocol of Schmidt et al. (17). Formation of advanced glycation end products was followed by measuring the time-dependent increase of fluorescence at $440 \mathrm{~nm}$ when excited at $370 \mathrm{~nm}$ according to Monnier and Cerami (22). The AGE-BSA solution was then lyophilized and redissolved in $50 \mathrm{ml}$ of bidistilled water. Glucose and other compounds were removed by extensive dialysis against $5 \times 51$ bidistilled water for $72 \mathrm{hr}$. Residual glucose was less than $0.1 \mathrm{mM}$ after this procedure. The dialyzed AGE-BSA was again lyophilized resulting in a brownish powder. Shortly before use, AGE-BSA was redissolved in $50 \mathrm{mM}$ phosphate-buffered saline (PBS). Control BSA was incubated under the same conditions but in absence of glucose. To minimize endotoxin contamination, all batches were further purified by chromatography on a polymyxin column (Pierce, München, Germany) and tested for the presence of endotoxin by the LAL-test (E-TOXATE, Sigma). CML content was measured by high performance liquid chromatography (HPLC) and enzyme-linked immunosorbent assay (ELISA) and showed approximately $20 \mathrm{Mol}$ CML/Mol albumin. Fructoselysin content was found to be low (approximately $0.3 \mathrm{Mol}$ FL/Mol albumin) under these conditions as determined by the reduction of nitroblue tetrazolium at alkaline $\mathrm{pH}$ using dihydroxyacetone as a standard (23).

\section{Cell Culture}

Preparation and cell culture of primary cardiac ventricular fibroblasts from adult male Wistar rats were performed as described (24). Briefly, two 300-400 g male Wistar rats were anaesthetized with $60 \mathrm{mg} / \mathrm{kg}$ ketaminehydrochloride (Ketavet, Parke-Davis, Berlin, Germany), $3 \mathrm{mg} / \mathrm{kg}$ xylacine (Rompun, Bayer AG, Leverkusen, Germany), and heparine (Thrombophob, Nordmark, Uetersen, Germany). The hearts were excised, mounted on a Langendorff system, and rinsed with perfusion buffer (PB) [containing (in $\mathrm{mM}$ ) $\mathrm{NaCl} 110, \mathrm{KCl} 2.6, \mathrm{KH}_{2} \mathrm{PO}_{4} 1.2, \mathrm{MgSO}_{4} 1.2$, $\mathrm{NaHCO}_{3} 25$, glucose 11$]$, at $37^{\circ} \mathrm{C}$ continuously gassed with $95 \% \mathrm{O}_{2} / 5 \% \mathrm{CO}_{2}$. Perfusion was continued by recirculating $\mathrm{PB}$ for $20 \mathrm{~min}$, containing $0.25 \mathrm{mg} / \mathrm{ml}$ collagenase P (Boehringer, Mannheim, Germany) and 12.5 $\mu \mathrm{M} \mathrm{CaCl}_{2}$. The ventricles of the hearts were then cut with a tissue chopper into $0.7 \times 0.7 \mathrm{~mm}$ pieces and incubated for another $10 \mathrm{~min}$ in $30 \mathrm{ml}$ reperfusion buffer, containing $400 \mathrm{mg}$ BSA. The material was filtered through a $250-\mu \mathrm{m}$ nylon mesh, spun down at $25 \mathrm{~g}$ for $3 \mathrm{~min}$, and the resulting pellet was resuspended and centrifuged another two times at $25 \mathrm{~g}$ for 3 min. Afterward, the supernatants of the three centrifugation steps were collected and spun down at $250 \mathrm{~g}$ for 5 minutes. The pellet was resuspended in DMEM medium $/ 10 \%$ calf serum and plated on six 12-well plates (Falcon, BD, Heidelberg, Germany). Two to four hours later, the debris and nonattached cells were removed by medium changes. The medium was changed the next day and the cells were grown for 5 days in DMEM medium containing $10 \%$ calf serum without another medium change. The culture contains more than $\mathbf{9 0} \%$ fibroblasts. Fibroblasts were passaged once into experimental dishes.

\section{Western Blot}

Western blots were performed as previously described (25). Briefly, cells were lysed in $50 \mathrm{mM}$ Tris/ $\mathrm{HCl}, \mathrm{pH} 6.7,2 \%$ SDS, $1 \mathrm{mM} \mathrm{Na} \mathrm{VO}_{4}$, followed by digestion of nucleic acids with benzonase (Merck, Darmstadt, Germany). Before adding 2\% mercaptoethanol, protein concentration was analyzed using the BCA assay of Bio-Rad, München, Germany. Equal amounts of lysates were resolved on $10 \%$ SDS-PAGE and transferred onto a nitrocellulose membrane by semidry blotting. After transfer, the membrane was blocked by $2 \%$ BSA in $50 \mathrm{mM}$ Tris, $150 \mathrm{mM} \mathrm{NaCl}$, and $0.2 \%$ NP40. Then the sheet was incubated with primary antibody (polyclonal P-specific antibodies, New England Biolabs, Frankfurt, Germany), $1 \mu \mathrm{g} / \mathrm{ml}$, in $50 \mathrm{mM}$ Tris, $150 \mathrm{mM} \mathrm{NaCl}, 0.2 \% \mathrm{NP} 40,2 \% \mathrm{BSA}$ ) for $1 \mathrm{hr}$. After washing three times with washing buffer ( $50 \mathrm{mM}$ Tris, $150 \mathrm{mM} \mathrm{NaCl}, 0.2 \%$ NP40), horseradish peroxidase-conjugated goat anti-rabbit IgG antibody (1:5000, Dianova, Hamburg, Germany) was added for an incubation time of $1 \mathrm{hr}$. The membrane 
was washed again three times with washing buffer. Subsequently, chemiluminescence detection was performed, using luminol and p-coumaric acid as enhancer.

\section{RNA Preparation}

Total RNA was prepared by phenol extraction using the Trizol reagent (Life Technologies, Eggenstein, Germany). Cells in $10-\mathrm{cm}$ dishes were rinsed with cold PBS, covered with $7 \mathrm{ml}$ of Trizol reagent, scraped, and subsequently transferred into a centrifuge tube. Two milliliters of phenol/chloroform were added, mixed, followed by a 15-min centrifugation step at $10,000 \mathrm{rpm}, 4^{\circ} \mathrm{C}$, in a SS-34 rotor. The upper aqueous phase was transferred into a new tube and $3.75 \mathrm{ml}$ of isopropanol was added for precipitation. By another 10 min centrifugation step at $10,000 \mathrm{rpm}$, a pellet was formed at the bottom of the tube. All liquid was removed and the pellet was washed with $7 \mathrm{ml}$ of ice-cold $75 \%$ ethanol in DEPCtreated water. After mixing, a final centrifugation step at $7500 \mathrm{rpm}$ recollected the pellet on the bottom of the tube. Ethanol was removed and the pellet was left to dry for $2 \mathrm{~min}$. The RNA pellet then was solved in $100 \mu$ l RNase-free water. The RNA was further purified using the Quiagen Total RNeasy kit according to manufacturer instructions. RNA concentration was determined by UV extinction at $260 \mathrm{~nm}$.

\section{Reverse Transcriptase-Polymerase Chain Reaction}

Reverse transcription was performed using the Superscript II reverse transcription system (Life Technologies). A mixture of $2 \mu \mathrm{g}$ total RNA, $2 \mu \mathrm{l}$ Oligo dT18 primer $(250 \mu \mathrm{g} / \mathrm{ml})$, and RNase-free water was set up to a volume of $12 \mu \mathrm{l}$ and heated at $70^{\circ} \mathrm{C}$ for $10 \mathrm{~min}$, then chilled on ice. Four microliters of $5 \times$ First Strand Buffer, $2 \mu \mathrm{l} 0.1 \mathrm{M}$ DTT, and $1 \mu \mathrm{l} 10 \mathrm{mM}$ dNTP were added. Contents were mixed and incubated at $42^{\circ} \mathrm{C}$ for $2 \mathrm{~min}$. Finally, $1 \mu \mathrm{l}$ Superscript II was added and the mix was incubated at $42^{\circ} \mathrm{C}$ for $50 \mathrm{~min}$. The reaction was stopped by heating at $70^{\circ} \mathrm{C}$ for $15 \mathrm{~min}$. The obtained cDNA was used as a template for TouchDown polymerase chain reaction (PCR).

\section{Touch-Down PCR}

PCR amplification was performed with the Quiagen PCR Taq Master kit (Hilden, Germany). $1 \mu$ l cDNA was mixed with $12.5 \mu \mathrm{l}$ PCR Taq Master mix, $2 \mu \mathrm{l}$ of $10 \mu \mathrm{M}$ primer mix (sense and anti-sense) and $9.5 \mu \mathrm{l}$ distilled water to a reaction volume of $25 \mu \mathrm{l}$. For proper results, a touch-down program was designed as follows: $94^{\circ} \mathrm{C}$ for $2 \mathrm{~min}$; cycles $1-5,94^{\circ} \mathrm{C}$ for $30 \mathrm{sec}$, $65^{\circ} \mathrm{C}$ for $30 \mathrm{sec}, 72^{\circ} \mathrm{C}$ for $60 \mathrm{sec}$; cycles $6-10,94^{\circ} \mathrm{C}$ for $30 \mathrm{sec}, 60^{\circ} \mathrm{C}$ for $30 \mathrm{sec}, 72^{\circ} \mathrm{C}$ for $60 \mathrm{sec}$; remaining cycles, $94^{\circ} \mathrm{C}$ for $30 \mathrm{sec}, 55^{\circ} \mathrm{C}$ for $30 \mathrm{sec}, 72^{\circ} \mathrm{C}$ for $60 \mathrm{sec}$; $72^{\circ} \mathrm{C}$ for $2 \mathrm{~min}$. Primers were designed with the Primer3-online-interface provided by the Whitehead Institute for Biomedical Research at http://wwwgenome.wi.mit.edu/cgi-bin/primer/primer3.cgi. Respective primer and product specifications are listed in Table 1.

\section{Preparation of Nuclear Protein Extracts}

Nuclear protein extracts [for determination of nuclear NF- $\kappa$ B by electrophoretic mobility shift assay (EMSA)] were prepared essentially as described (26). Briefly, PBS-washed fibroblasts were scraped from the culture plate and collected by centrifugation. Pellets were resuspended in $0.4 \mathrm{ml}$ of hypotonic lysis buffer containing $10 \mathrm{mM}$ Hepes $(\mathrm{pH} 7.9), 10 \mathrm{mM}$ $\mathrm{KCl}, 0.1 \mathrm{mM}$ EDTA, $0.1 \mathrm{mM}$ EGTA, $1 \mathrm{mM}$ DTT, and $0.5 \mathrm{mM}$ phenylmethylsulfonylfluoride (PMSF). After 15 min on ice, Nonidet P40 was added to a final concentration of $0.5 \%$. The cells were mixed for $10 \mathrm{sec}$ and then centrifuged for $30 \mathrm{sec}$ at $12,000 \mathrm{~g}\left(4^{\circ} \mathrm{C}\right)$. The pellets containing the nuclei were resuspended in $140 \mu \mathrm{l}$ buffer containing $20 \mathrm{mM}$ Hepes (pH 7.9), $0.4 \mathrm{mM} \mathrm{NaCl}$, ImM EDTA, 1 mM EGTA, 1 mM DTT, and $1 \mathrm{mM}$ PMSF and mixed for $30 \mathrm{~min}$ at $4^{\circ} \mathrm{C}$. After centrifugation $\left(5 \mathrm{~min}, 4^{\circ} \mathrm{C}, 12,000 \mathrm{~g}\right)$, the supernatant (nuclear extract) was stored at $-80^{\circ} \mathrm{C}$.

\section{EMSA}

The EMSA was done as described previously (27). The oligonucleotides representing the consensus sequence for NF- $\kappa$ B (5' -AGC TTC AGA GGG GAC TTT CCG AGA GG - $3^{\prime}$ and $5^{\prime}$ TCG ACC TCT CGG AAA GTC CCC TCT GA-3') were hybridized to form a double-stranded probe, and the ends were ${ }^{32} \mathrm{P}$-labeled with Klenow-polymerase. The binding reactions were performed on ice in a volume of $15 \mu \mathrm{l}$, containing $5 \mu \mathrm{l}$ of $3 \times$ binding buffer [60 mM Hepes ( $\mathrm{pH} 7.9$ ), $1 \mathrm{mM}$ DTT, $3 \mathrm{mM}$ EDTA, $150 \mathrm{mM} \mathrm{KCl}$ and $12 \%$ Ficoll], $20,000 \mathrm{cpm}$ of ${ }^{32} \mathrm{P}$-labelled DNA-probe, $7 \mu \mathrm{g} \mathrm{nu}-$ clear proteins, and $2 \mu \mathrm{g}$ poly dIdC (BoehringerMannheim). After $30 \mathrm{~min}$ on ice, the complexes were separated on a native $5 \%$ polyacrylamide gel and scanned. For the supershift assays, the anti-p50 antibody was included at concentration of $1 \mathrm{mg} / \mathrm{ml}$ in the EMSA standard reaction mixture $20 \mathrm{~min}$ before the addition of the labeled oligonucleotides.

\section{Zymography}

Conditioned media were directly loaded onto electrophoretic gels (SDS-PAGE) containing $1 \mathrm{mg} / \mathrm{ml}$ of gelatin (28) or collagen (type I acid soluble) under nonreducing conditions. The gels were run at $15 \mathrm{~mA}$ through the stacking phase $(4 \%)$ and at $20 \mathrm{~mA}$ for the separating phase $(10 \%)$. After SDS-PAGE, the gels were washed twice in $2.5 \%$ Triton $\mathrm{X}-100$ for $30 \mathrm{~min}$ each at room temperature, rinsed in water, and incubated for $18 \mathrm{hr}$ in a substrate buffer at $37^{\circ} \mathrm{C}$ $(50 \mathrm{mmol} / \mathrm{L}$ Tris- $\mathrm{HCl}, 0.15 \mathrm{~mol} / \mathrm{L} \mathrm{NaCl}, 5 \mathrm{mmol} / \mathrm{L}$ $\mathrm{CaCl}_{2}$ and $0.05 \%$ Brij 35, pH 7.5). After incubation, the gels were stained using $0.5 \%$ Coomassie Brilliant Blue R-250 and destained with 40\% methanol and $10 \%$ acetic acid. Molecular weights were determined using standard prestained molecular weight markers (Bio-Rad). All reagents for electrophoresis were purchased from Sigma. Gelatinolytic bands were measured with an image analyzer (Gel Doc 2000, Bio-Rad, München, Germany). 
Table 1. Primers used for RT-PCR

\begin{tabular}{|c|c|c|c|c|}
\hline Name & Primer Sequence & Product Size & Tm/Cycles & GeneBankNo \\
\hline Collagen 1 (52) & $\begin{array}{l}\text { se: CCC ACG TAG GTG TCC TAA AGT } \\
\text { as: CCG TGG TGC TAA AAT AAT AAA }\end{array}$ & $\begin{array}{c}346 \mathrm{bp} \\
(1012-1358)\end{array}$ & $55 / 30$ & KO1832 \\
\hline Collagen 3 (52) & $\begin{array}{l}\text { se: CGAGGTAACAGAGGTGAAAGA } \\
\text { as: AACCCAGTATTCTCCGCTCTT }\end{array}$ & $\begin{array}{c}336 \mathrm{bp} \\
(797-1132)\end{array}$ & $55 / 30$ & AJ005395 \\
\hline Collagen 4 (53) & $\begin{array}{l}\text { se: GGGAGCATGAAGGGACAG } \\
\text { as: CAGGGCCTTGCTGGCTTC }\end{array}$ & $\begin{array}{c}393 \mathrm{bp} \\
(2961-3353)\end{array}$ & $55 / 30$ & J04694 \\
\hline Fibronectin (54) & $\begin{array}{l}\text { se: GAGAGATCTGGAGGTCAT } \\
\text { as: GGGTGACACCTGAGTGAA }\end{array}$ & $\begin{array}{c}853 \text { bp } \\
(4830-5682)\end{array}$ & $55 / 22$ & X15906 \\
\hline Laminin & $\begin{array}{l}\text { se: CCACCTCTGAACACCAAGGC } \\
\text { as: TGTTCTCTGGGGCTGATGGT }\end{array}$ & $\begin{array}{c}413 \text { bp } \\
(4420-4832)\end{array}$ & $55 / 30$ & U61261 \\
\hline MMP-2 & $\begin{array}{l}\text { se: AGCTCATCGCAGACTCCTGG } \\
\text { as: CAGCACCTTTCTTTGGGCAC }\end{array}$ & $\begin{array}{c}362 \text { bp } \\
(2426-2787)\end{array}$ & $55 / 22$ & X71466 \\
\hline MMP-7 & $\begin{array}{l}\text { se: TTTGATGGGCCAGGAAACAC } \\
\text { as: TGTGCAAAACCCATCCACAG }\end{array}$ & $\begin{array}{l}398 \mathrm{bp} \\
(574-971)\end{array}$ & $55 / 30$ & L24374 \\
\hline MMP-9 & $\begin{array}{l}\text { se: CTACTGGCACACGCCTTTCC } \\
\text { as: CCGAGCGACCTTTAGTGGTG }\end{array}$ & $\begin{array}{l}385 \text { bp } \\
(589-973)\end{array}$ & $55 / 30$ & U36476 \\
\hline MMP-13 & $\begin{array}{l}\text { se: ACCTGGACAAGCAGCTCCAA } \\
\text { as: CAGGGCCCAGAATTTTCTCC }\end{array}$ & $\begin{array}{c}456 \mathrm{bp} \\
(602-1057)\end{array}$ & $55 / 35$ & M60616 \\
\hline $\begin{array}{l}\text { MT-MMP } \\
(\text { MMP-14) }\end{array}$ & $\begin{array}{l}\text { se: CAAGTCAGC^^TCTGCGGGACT } \\
\text { as: CAGGATGGGTGAGAACAGCC }\end{array}$ & $\begin{array}{c}379 \text { bp } \\
(1749-2127)\end{array}$ & $55 / 30$ & X91785 \\
\hline TIMP-I & $\begin{array}{l}\text { se: CATGGGTTCCCCAGAAATCA } \\
\text { as: AGTTTGCAAGGGATGGCTGA }\end{array}$ & $\begin{array}{c}366 \mathrm{bp} \\
(162-527)\end{array}$ & $55 / 22$ & U06179 \\
\hline TIMP-2 (55) & $\begin{array}{l}\text { se: CAAAGGACCTGACAAGGAC } \\
\text { as: TTGATGCAGGCAAAGAAC }\end{array}$ & $\begin{array}{c}348 \text { bp } \\
(445-792)\end{array}$ & $55 / 25$ & L31884 \\
\hline TGF-beta 1 (56) & $\begin{array}{l}\text { se: ACGTCAGACATTCGGGAAGCAGTG } \\
\text { as: GCAAGGACCTTGCTGTACTGTGTG }\end{array}$ & $\begin{array}{c}611 \mathrm{bp} \\
(824-1434)\end{array}$ & $55 / 28$ & X52498 \\
\hline GAPDH & $\begin{array}{l}\text { se: TGGAAAGCTGTGGCGTGATG } \\
\text { as: TCCACCACCCTGTTGCTGTAGC }\end{array}$ & $\begin{array}{c}402 \mathrm{bp} \\
(600-1001)\end{array}$ & $55 / 20$ & M17701 \\
\hline
\end{tabular}

Abbreviations: se, sense; as, antisense

Control of specific MMP activity was carried out using an incubation buffer containing 25 mM EDTA.

\section{Statistics}

Pictures from the PCR reactions and Western blots were scanned and analyzed densitometrically using NIH-image. Zymograms were analyzed using the GelDoc 2000 system as mentioned. The statistical analysis was done by ANOVA using SPSS statistical package. A $p$-value of 0.05 was considered statistically significant. All experiments were done in duplicate using three independent cell preparations.

\section{Results}

AGE-BSA Activates Specific Signaling Pathways

in Cardiac Fibroblasts

A frequently found cell response to AGEs, described for endothelial cells and macrophages, is an activation of the transcription factor $\mathrm{NF}-\kappa \mathrm{B}$ in parallel to intracellular oxidative stress (29). To examine a possible $\mathrm{NF}-\kappa \mathrm{B}$ activation by AGEs in cardiac fibroblasts, an EMSA was performed. Nuclear extracts of cardiac fibroblasts stimulated for $24 \mathrm{hr}$ with AGE-BSA at a concentration of $25 \mu \mathrm{M}$ were compared to those of BSA-treated and untreated cells. As shown in Figure 1, an induction of NF- $\kappa \mathrm{B}$ in cardiac fibroblasts by AGEs could be demonstrated, which was not seen in BSA-treated samples.

To further determine early cell responses to AGEs, we examined the activation of several protein kinases representing different signaling pathways. Cardiac fibroblasts were grown to confluence and subsequently stimulated with AGE-modified BSA or unmodified BSA as controls. First, we investigated the three MAPkinase pathways resembled by the p44/42-MAPkinase/ERK kinases, the SAPK/JNK, and the p38MAP-kinase. As shown in Figure 2, we detected a 5.5-fold induction of the p44/42-MAP-kinase with a maximum after 30 min of AGE stimulation, subsequently decreasing again to a basic activation level. In addition, a small but distinct activation (1.9-fold) of 


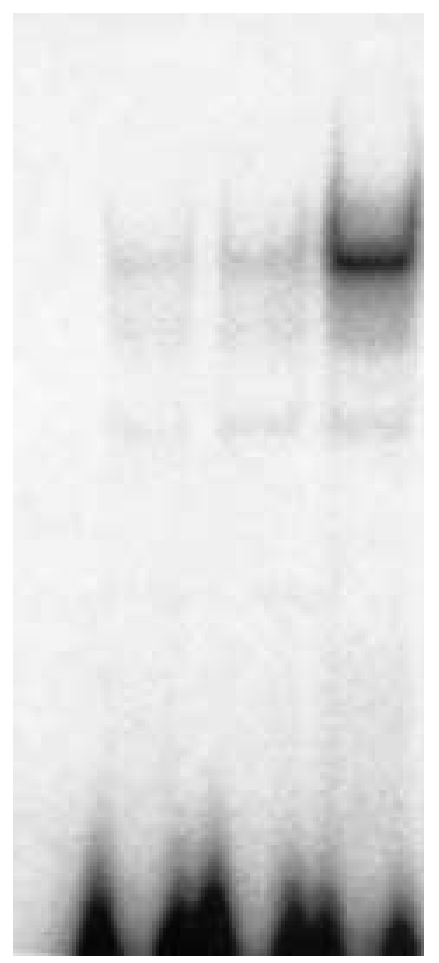

Fig. 1. AGE-BSA induces activation of NF- $\kappa$ B in cardiac fibroblasts. Quiescent confluent cardiac primary fibroblasts from the adult rat were incubated with $25 \mu \mathrm{M}$ AGE-BSA or BSA for $24 \mathrm{hr}$. Translocation of NF- $\kappa$ B was measured by EMSA of nuclear extracts as described in the Methods section. The shifted band in the AGEBSA lane represents active NF- $\kappa$ B. C, nontreated controls.

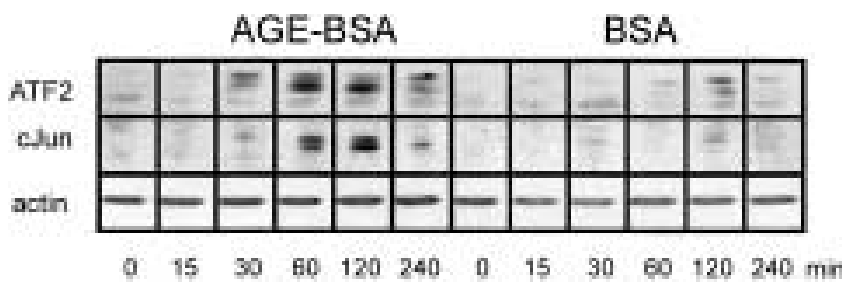

Fig. 3. AGE-BSA stimulates phosphorylation of transcription factors. Quiescent confluent cardiac primary fibroblasts from the adult rat were incubated with $25 \mu \mathrm{M}$ AGE-BSA or BSA for the indicated times. Activation of transcription factors ATF-2 and c-jun was analyzed by immunoblotting using phosphospecific antibodies. Cardiac fibroblasts were stimulated as described in Figure 2. For analysis, phosphospecific antibodies representing activation sites for the transcription-factors ATF-2 and c-jun were used.

and ATF-2. Indeed, AGE stimulation increases both c-jun and ATF2 phosphorylation (Fig. 3). Whereas the p42/44 MAPK as well as p38-MAP-kinase phosphorylation was maximal between 30 to 60 min after stimulation, the phosphorylation of the downstream targets ATF- 2 and c-jun was maximal between 60 and 120 min (Figs. 2 and 3).

Next, different AGE-BSA concentrations were tested to determine the AGE concentration required for a significant activation of the described signaling pathways. AGE-levels of 0, 3, 6, 12, 25, and $50 \mu \mathrm{M}$ were applied for cell stimulation. Similar BSA concentrations served as controls. As Figure 4 shows, even at an AGE concentration of $3 \mu \mathrm{M}$, a slight activation of both p44/42-MAPK and the ATF2 transcription factor was observed. The maximal activation was reached at $12.5 \mu \mathrm{M}$ or $25 \mu \mathrm{M}$ AGE-BSA for ATF-2 or the MAP-kinase, respectively. Activation of p38-MAP-kinase and SAPK/JNK gave similar results (data not shown).

In summary, AGE-BSA, but not BSA stimulation, exerted an activation of the p42/44-MAPK, SAPK/JNK and the p38-MAPK in a time- and concentration-dependent manner. The downstream transcription factors C-Jun and ATF2 as well as NF- $\kappa$ B were activated by AGE-BSA in cardiac fibroblasts.

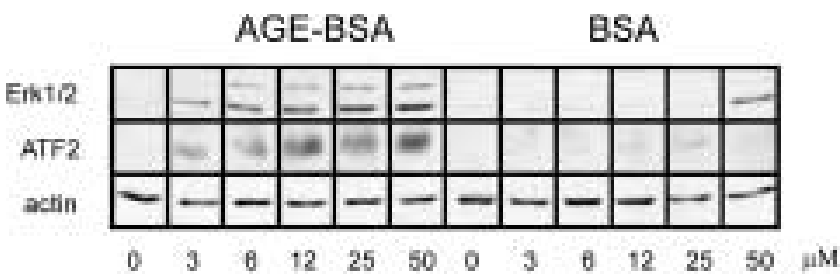

Fig. 4. Concentration dependent stimulation of cellular signaling. Quiescent cardiac fibroblasts were stimulated with indicated amounts of AGE-BSA/BSA for $45 \mathrm{~min}$ (ERK-1/2) or $90 \mathrm{~min}$ (ATF-2). Cell lysates were prepared and the activation of these proteins analyzed by immunoblotting using phosphospecific antibodies. 


\section{AGE-BSA Modifies the Expression of ECM-Related Genes in Cardiac Fibroblasts}

Cardiac fibroblasts are the key regulators of the ECM composition of the heart. A balance of the different components of the ECM network is essential for unrestricted heart function. To detect a possible interference of AGEs, the expression of relevant genes in response to AGEs was examined by reverse transcriptase polymerase chain reaction (RT-PCR). Gene expression was measured from cells stimulated with $25 \mu \mathrm{M}$ AGE-BSA for 0, 4, 8, 16, 32, and $64 \mathrm{hr}$ in comparison to controls treated with BSA. c-DNA probes in use were primarily tested for GAPDH expression to exclude differences in template concentrations.

A first target was TGF- $\beta 1$ expression, because TGF- $\beta 1$ has been found up-regulated in epithelial cells after AGE stimulation, and a contributory effect of TGF- $\beta 1$ to heart fibrosis by triggering collagen expression has been postulated. However, as shown in Figure 5A, we could not detect any changes in TGF$\beta 1$ expression.

As a next step, the expression of the most abundant ECMs in the heart-collagen I, collagen III, collagen IV, laminin, and fibronectin-was examined. Interestingly, we did not find any up-regulation of these genes (Fig. 5B). Collagen III even appeared to be down-regulated by AGE stimulation, whereas expression levels of collagen I, collagen IV, and fibronectin remained unchanged.

An important group of ECM-related genes in the myocardium are the MMPs and their inhibitors (TIMPs). These are considered the driving force for ECM remodeling. Elevated activity and expression of MMPs in cardiac tissue are found in heart fibrosis and
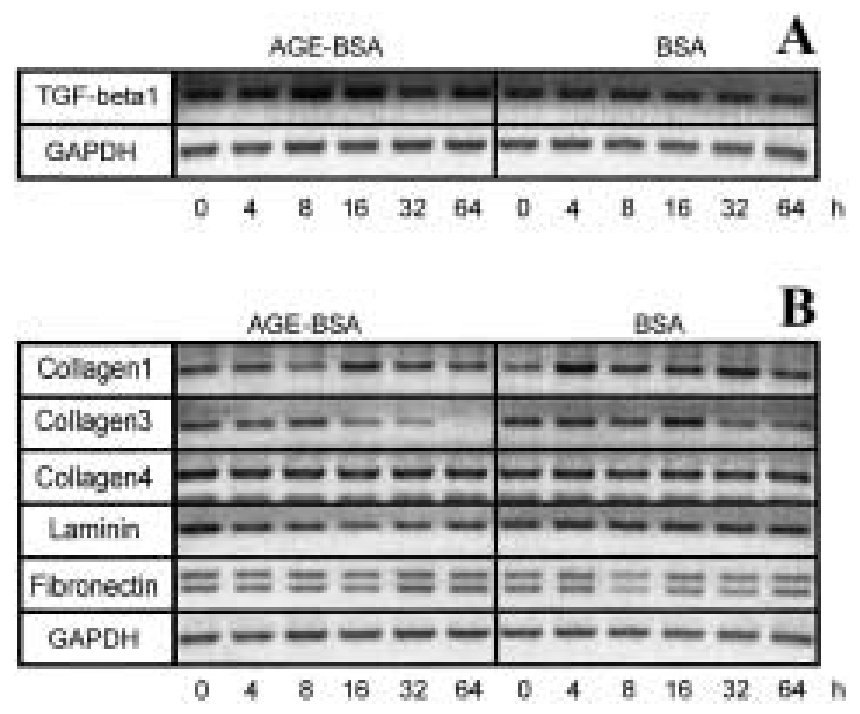

Fig. 5. Effect of AGE-BSA on expression of ECM proteins. Quiescent confluent cardiac primary fibroblasts from the adult rat were incubated with $25 \mu \mathrm{M}$ AGE-BSA or BSA for the indicated times. Expression of ECM proteins was determined by RT-PCR as described in the Methods section. heart failure. We examined the MMPs collagenase 3 (MMP13), gelatinase A and B (MMP2, MMP9), matrilysin (MMP7), and membrane type l MMP (MMP14) as well as the tissue inhibitors of metalloproteinases, TIMP1 and TIMP2.

A rapid up-regulation of MMP2, MMP9, and MMP13 was distinctly detectable, followed by a slight up-regulation of TIMPI (Fig. 6). These results are confirmed by enhanced activity of MMP2 and MMP13 as detected by the zymographic assay (Fig. 7).

\section{Discussion}

Cardiac fibrosis is characterized not only by an increase of ECM proteins, but also by alterations in collagen types and organization (30). Therefore, fibrosis is associated with an increased expression and activity of MMPs (31). Reactive fibrosis can be induced by various stimuli such as chronic elevations of hormones and immune complexes (31). Our in vitro results indicate that elevated levels of AGEs can be an additional profibrotic factor in the heart. The most prominent characteristic of AGE-induced activation of primary cardiac fibroblasts is a change in MMP expression. In particular, MMP2 levels are significantly raised; furthermore, levels of MMP9 and MMP13 are increased. Levels of MMP7 and membrane-associated MMP (MT-MMP, MMP14) are not altered. In contrast, expression patterns of collagens and other ECM proteins were not changed with the exception of collagen III, which seems to be down-regulated. These findings are in contrast to the so far best characterized example of AGEinduced fibrosis, the glomerosclerosis in the diabetic kidney $(15,32)$. In this case, induction of ECM proteins itself rather than enzymes acting on ECM proteins was observed $(33,34)$.

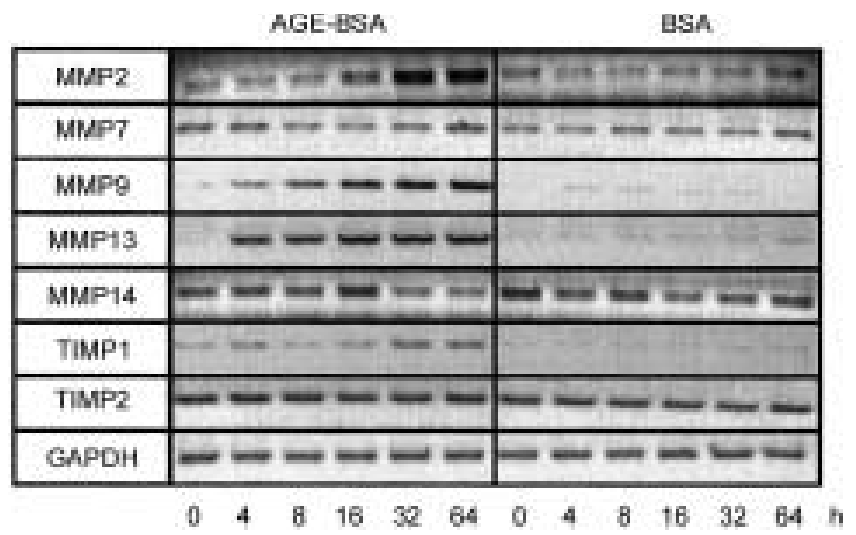

Fig. 6. Effect of AGE-BSA on expression of metalloproteases and their inhibitors (TIMP). Quiescent confluent cardiac primary fibroblasts from the adult rat were incubated with $25 \mu \mathrm{M}$ AGE-BSA or BSA for the indicated times.

Expression of MMPs and TIMPs was determined by RT-PCR as described in the Methods section. 

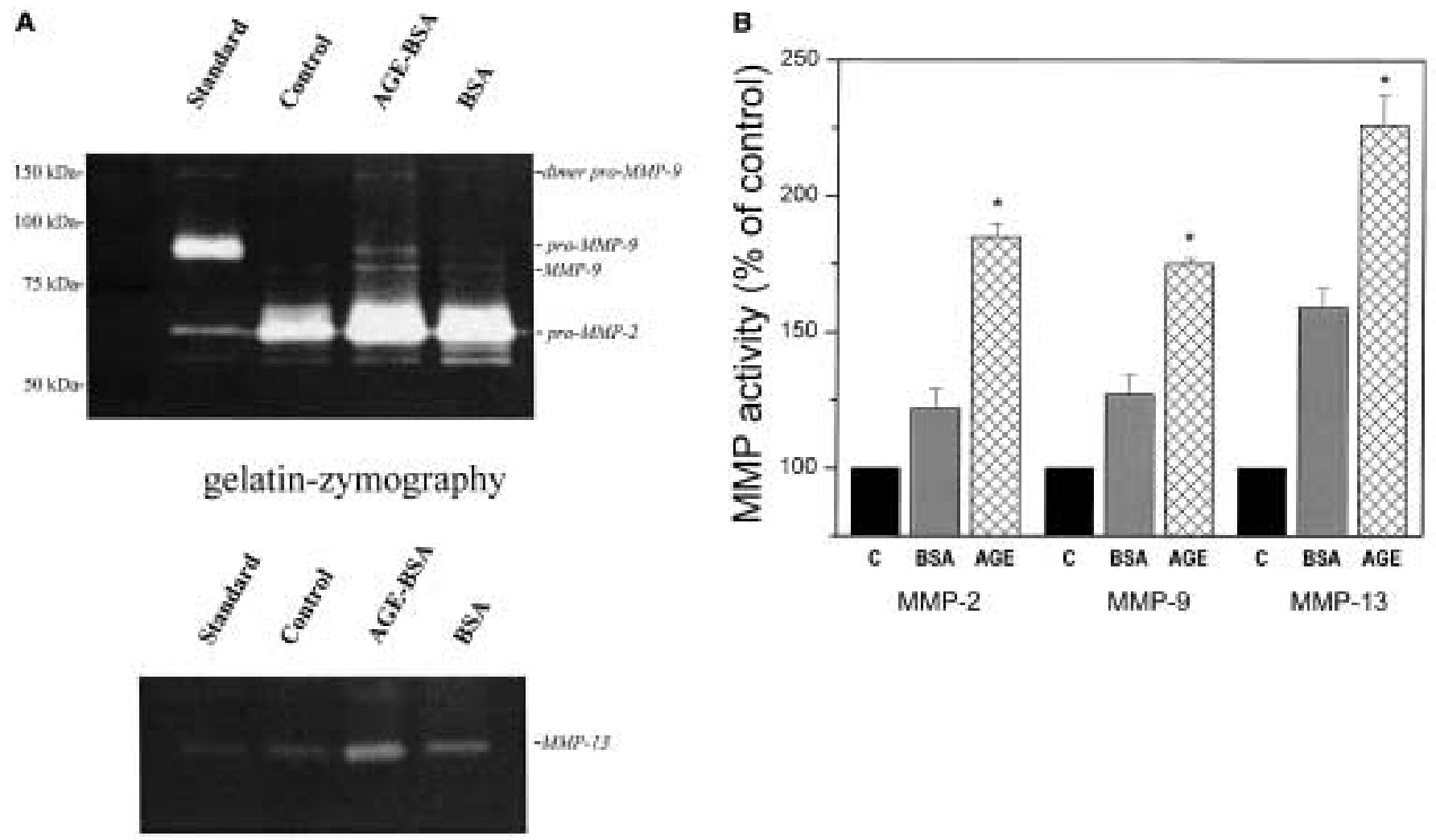

collagen-zymography

Fig. 7. Effect of AGE-BSA on activity of metalloproteases. Quiescent confluent cardiac primary fibroblasts from the adult rat were incubated with $25 \mu \mathrm{M}$ AGE-BSA or BSA for $24 \mathrm{hr}$. MMP activity was determined by Zymograms of cell culture supernatants as described in the methods section. (A) Analysis of MMP activity in gelatin and collagen zymograms. (B) Relative activation of MMPs by AGE-BSA as determined by densitometry of Zymograms. Shown are the means and the SEM of three independent experiments. *Significant in comparison to appropriate controls $(p<0.05)$.

One major inductor of cardiac fibrosis certainly is TGF- $\beta 1$, due to enhanced angiotensin II formation $(35,36)$. However, the fact that collagen and other matrix proteins are not induced in the presence of AGEs indicates that TGF- $\beta 1$-mediated expression of ECM proteins seems not to play a central role in AGE-induced fibrosis in primary cardiac fibroblasts. The failure of AGEs to induce TGF- $\beta 1$ expression in cardiac primary fibroblasts further corroborates this finding. However, our results do not exclude an indirect TGF- $\beta 1$-mediated activation of cardiac fibroblasts in vivo, because induction of TGF- $\beta 1$ expression by AGEs has been demonstrated for other cells types such as macrophages/monocytes or epithelial cells (29) (Xiang et al., unpublished results). This in turn may lead to enhanced in vivo production of ECM by stimulation of cardiac fibroblasts.

The action pattern of AGEs on cardiac fibroblasts such as modulation of MMP activities resembles rather that of other cytokines-including TNF- $\alpha$ and
ILl- $\beta$-than that of TGF- $\beta$ 1. These cytokines have been shown to enhance or inhibit collagen production in fibroblasts most likely by modulation of MMP activities. On the one hand, TNF- $\alpha$ has been shown to be increased in severe chronic heart failure (37); on the other hand, in vitro studies have demonstrated that activity of MMPs is increased in cardiac and other cells after stimulation by TNF- $\alpha(38,39)$.

Most inducible MMP genes contain an AP-1 binding site, indicating that AP-1 plays a major although not exclusive role in transcriptional activation of MMPs $(31,40,41)$. This has been confirmed for the regulation of MMP-1 $(42,43)$. The AGEinduced phosphorylation of c-jun in primary cardiac fibroblasts indicates that the transcription factor AP-1 also plays a role in the observed changes in MMP expression. Activation of AP-1 transcription factor is mediated by the three MAPK pathways and activation of MMPs has been shown to be dependent on these pathways (44). In skin fibroblasts, a coordi- 
nate activation of all three MAPK pathways has been observed after stimulation with cytokines or okadaic acid $(45,46)$. AGEs, which have been shown to induce the ERK1/2 pathway in smooth muscle cells and tubular cells $(20,21)$, also activate the ERK1/2 pathway as well as the p38-Kinase and-to a lesser extent-the JNK/SAPK pathway in primary cardiac fibroblasts. Treatment of these cells with BSA alone led to a faint activation, which may be due to naturally occurring AGE modification of albumin. Therefore, it is very probable that activation of MMP in primary fibroblasts is induced by AGEs via the MAPK pathways.

A hallmark of AGE-induced activation of different types of cells seems to be activation of transcription factor NF- $\kappa \mathrm{B}(27,29,47)$. For primary cardiac fibroblasts, a clear activation of NF- $\kappa \mathrm{B}$ was observed. Although NF- $\kappa$ B appears not to be a central mediator of MMP activation, the gene of MMP-9 contains a NF- $\kappa$ B binding site (40). Furthermore, it has been shown that NF- $\kappa \mathrm{B}$-beside AP- 1 -is involved in regulation of MMP-9 in mesangial cells (48). Because MMP-9 induction is prominent in cardiac fibroblasts after incubation with AGEs, it can be proposed that NF- $\kappa \mathrm{B}$ plays a role in the coordinate activation of in particular MMP-9. On the other hand, it has been shown that TNF- $\alpha$-induced activation of NF- $\kappa$ B results in decreased expression of alphal (I) collagen in fibroblasts (49). This may explain our finding that collagen expression is not affected or even reduced by AGEs.

In cardiac fibrosis, MMPs interplay with their inhibitors (TIMPs) in a complex, not yet fully understood manner $(31,50)$. However, in general, TIMPs are decreased in the failing heart (51). Our results show little effect of AGEs on TIMP expression in cardiac fibroblasts, indicating that MMP activity is not counteracted by their inhibitors. In the case of TIMP-1, a delayed expression is observed pointing to the onset of regulatory processes to reduce MMP activity.

Cardiac fibrosis is not only defined as an increase in the concentration of matrix components, but also in terms of changes of collagen organization and MMP expression patterns $(30,31)$. Because similar changes were found in fibroblasts incubated with AGEs, the observed AGE-induced expression pattern resembles the situation during cardiac remodeling. Although these findings are based on in vitro data, in the light of the effects of AGE inhibitors on the diseased or aged heart $(11,12)$, our results support the hypothesis that prolonged elevated levels of AGEs contribute to cardiac remodeling, which is an important step in the induction of cardiac fibrosis.

\section{Acknowledgment}

This work was supported by a grant from MUCOS Pharma GmbH, Germany.

\section{References}

1. Westwood ME, Thornalley PJ. (1997) Glycation and advanced glycation endproducts. In Colacao C, ed. The Glycation Hypothesis. City, TX: Landes Bioscience, Georgetown; pp 59-87.

2. Sell DR, Kleinman NR, Monnier VM. (2000) Longitudinal determination of skin collagen glycation and glycoxidation rates predicts early death in C57BL/6NNIA mice. FASEB J. 14: 145-156.

3. Schleicher ED, Wagner E, Nerlich AG. (1997) Increased accumulation of the glycoxidation product $\mathrm{N}$ (epsilon)(carboxymethyl)lysine in human tissues in diabetes and aging. J. Clin. Invest. 99: 457-468.

4. Bucala R, Vlassara H. (1995) Advanced glycosylation end products in diabetic renal and vascular disease. Am. J. Kidney Dis. 26: 875-888.

5. Brownlee M. (1995) Advanced Glycation Endproducts in diabetes and ageing. Annu. Rev. Med. 46: 223-234.

6. Raj DS, Choudhury D, Welbourne TC, Levi M. (2000) AGEs: A nephrologist's perspective. Am. J. Kidney. Dis. 35: 365-380.

7. Sun M, Yokoyama M, Ishiwata T, Asano G. (1998) Deposition of advanced glycation end products (AGE) and expression of the receptor for AGE in cardiovascular tissue of the diabetic rat. Int. J. Exp. Pathol. 79: 207-222.

8. Wolffenbuttel BH, Boulanger CM, Crijns FR, et al. (1998) Breakers of advanced glycation end products restore large artery properties in experimental diabetes. Proc. Natl. Acad. Sci. U.S.A. 95: 4630-4634.

9. Berg TJ, Snorgaard O, Faber J, et al. (1999) Serum levels of advanced glycation end products are associated with left ventricular diastolic function in patients with type 1 diabetes. Diabetes Care 22: 1186-1190.

10. Kilhovd BK, Berg TJ, Birkeland KI, Thorsby P, Hanssen KF. (1999) Serum levels of advanced glycation end products are increased in patients with type 2 diabetes and coronary heart disease. Diabetes Care 22: 1543-1548.

11. Asif M, Egan J, Vasan S, et al. (20000 An advanced glycation endproduct cross-link breaker can reverse age-related increases in myocardial stiffness [published erratum appears in Proc. Natl. Acad. Sci. U.S.A. 2000 97: 5679]. Proc. Natl. Acad. Sci. U.S.A. 97: 2809-2813.

12. Corman B, Duriez M, Poitevin P, et al. (1998) Aminoguanidine prevents age-related arterial stiffening and cardiac hypertrophy. Proc. Natl. Acad. Sci. U.S.A. 95: 1301-1306.

13. Sharma K, Ziyadeh FN. (1997) Biochemical events and cytokine interactions linking glucose metabolism to the development of diabetic nephropathy [published erratum appears in Semin. Nephrol. 1997 17: 391]. Semin. Nephrol. 17: 80-92.

14. Huang JS, Guh JY, Hung WC, et al. (1999) Role of the Janus kinase (JAK)/signal transducters and activators of transcription (STAT) cascade in advanced glycation end-productinduced cellular mitogenesis in NRK-49F cells. Biochem. J. 342: 231-238.

15. Yang CW, Vlassara H, Peten EP, He CJ, Striker GE, Striker LJ. (1994) Advanced glycation end products up-regulate gene expression found in diabetic glomerular disease. Proc. Natl. Acad. Sci. U.S.A. 91: 9436-9440.

16. Vlassara H, Striker LJ, Teichberg S, Fuh H, Li YM, Steffes M. (1994) Advanced glycation end products induce glomerular sclerosis and albuminuria in normal rats. Proc. Natl. Acad. Sci. U.S.A. 91: 11704-11708.

17. Schmidt AM, Hasu M, Popov D, et al. (1994) Receptor for advanced glycation end products (AGEs) has a central role in vessel wall interactions and gene activation in response to circulating AGE proteins. Proc. Natl. Acad. Sci. U.S.A. 91: 8807-8811.

18. Vlassara H, Fuh H, Donnelly T, Cybulsky M. (1995) Advanced glycation endproducts promote adhesion molecule (VCAM- I, ICAM-1) expression and atheroma formation in normal rabbits. Mol. Med. 1: 447-456.

19. Bierhaus A, Chevion S, Chevion M, et al. (1997) Advanced glycation end product-induced activation of NF-kappaB is suppressed by alpha-lipoic acid in cultured endothelial cells. Diabetes 46: 148114-148190. 
20. Lander HM, Tauras JM, Ogiste JS, Hori O, Moss RA, Schmidt AM. (1997) Activation of the receptor for advanced glycation end products triggers a p21(ras)-dependent mitogen-activated protein kinase pathway regulated by oxidant stress. J. Biol. Chem. 272: 17810-17814.

21. Simm A, Munch G, Seif F, et al. (1997) Advanced glycation endproducts stimulate the MAP-kinase pathway in tubulus cell line LLC-PK1. FEBS Lett. 410: 48148-48154.

22. Monnier VM, Cerami A. (1981) Nonenzymatic browning in vivo: possible process of aging of long-lived proteins. Science 211: 491-493.

23. Phillipou G, Seaborn CJ, Phillips PJ. (1988) Re-evaluation of the fructosamine reaction. Clin. Chem. 34: 1561-1564.

24. Simm A, Nestler M, Hoppe V. (1997) PDGF-AA, a potent mitogen for cardiac fibroblasts from adult rats. J. Mol. Cell. Cardiol. 29: 357-368.

25. Simm A, Hoppe V, Tatje D, Schenzinger A, Hoppe J. (1992) PDGF-AA effectively stimulates early events but has no mitogenic activity in AKR-2B mouse fibroblasts. Exp. Cell. Res. 201: 192-199.

26. Hauf N, Goebel W, Fiedler F, Sokolovic Z, Kuhn M. (1997) Listeria monocytogenes infection of $\mathrm{P} 388 \mathrm{D} 1$ macrophages results in a biphasic NF-kappaB (RelA/p50) activation induced by lipoteichoic acid and bacterial phospholipases and mediated by IkappaBalpha and IkappaBbeta degradation. Proc. Natl. Acad. Sci. U.S.A. 94: 9394-9399.

27. Neumann A, Schinzel R, Palm D, Riederer P, Munch G. (1999) High molecular weight hyaluronic acid inhibits advanced glycation endproduct-induced NF-kappaB activation and cytokine expression. FEBS Lett. 453: 283-287.

28. Kleiner DE, Stetler-Stevenson WG. (1994) Quantitative zymography: detection of picogram quantities of gelatinases. Anal. Biochem. 218: 325-329.

29. Bierhaus A, Hofmann M, Ziegler R, Nawroth P. (1998) AGEs and their interaction with AGE-receptors in vascular disease and diabetes. Cardiovasc. Res. 37: 586-600.

30. Whittaker P. (1995) Unravelling the mysteries of collagen and cicatrix after myocardial infarction. Cardiovasc. Res. 29: 758- 762.

31. Li YY, McTiernan CF, Feldman AM. (2000) Interplay of matrix metalloproteinases, tissue inhibitors of metalloproteinases and their regulators in cardiac matrix remodeling. Cardiovasc. Res. 46: 214-224.

32. Throckmorton DC, Brogden AP, Min B, Rasmussen H, Kashgarian M. (1995) PDGF and TGF-beta mediate collagen production by mesangial cells exposed to advanced glycosylation end products. Kidney Int. 48: 111-117.

33. Doi T, Vlassara H, Kirstein M, Yamada Y, Striker GE, Striker LJ. (1992) Receptor-specific increase in extracellular matrix production in mouse mesangial cells by advanced glycosylation end products is mediated via platelet-derived growth factor. Proc. Natl. Acad. Sci. U.S.A. 89: 2873-2877.

34. Ziyadeh FN, Han DC, Cohen JA, Guo J, Cohen MP. (1998) Glycated albumin stimulates fibronectin gene expression in glomerular mesangial cells: involvement of the transforming growth factor-beta system. Kidney Int. 53: 631-638.

35. Eghbali M, Tomek R, Sukhatme VP, Woods C, Bhambi B. (1991) Differential effects of transforming growth factor-beta 1 and phorbol myristate acetate on cardiac fibroblasts. Regulation of fibrillar collagen mRNAs and expression of early transcription factors. Circ. Res. 69: 483-490.

36. Weber KT. (1997) Fibrosis, a common pathway to organ failure: angiotensin II and tissue repair. Semin. Nephrol. 17: 467491.

37. Levine B, Kalman J, Mayer L, Fillit HM, Packer M. (1990) Elevated circulating levels of tumor necrosis factor in severe chronic heart failure. N. Engl. J. Med. 323: 236-241.

38. Brenner DA, O'Hara M, Angel P, Chojkier M, Karin M. (1989) Prolonged activation of jun and collagenase genes by tumour necrosis factor-alpha. Nature 337: 661-663.
39. Li YY, McTiernan CF, Feldman AM. (1999) Proinflammatory cytokines regulate tissue inhibitors of metalloproteinases and disintegrin metalloproteinase in cardiac cells. Cardiovasc. Res. 42: $162-172$.

40. Westermarck J, Kahari VM. (1999) Regulation of matrix metalloproteinase expression in tumor invasion. FASEB J. 13: 781792.

41. Auble DT, Brinckerhoff CE. (1991) The AP-1 sequence is necessary but not sufficient for phorbol induction of collagenase in fibroblasts. Biochemistry 30: 4629-4635.

42. Benbow U, Brinckerhoff CE. (1997) The AP-1 site and MMP gene regulation: what is all the fuss about? Matrix Biol. 15 519-526.

43. Doyle GAR, Pierce RA, Parks WC. (1997) Transcriptional induction of collagenase-1 in differentiated monocyte-like (U937) cells is regulated by AP-1 and an upstream C/EBPbeta site. J. Biol. Chem. 272: 11840-11849.

44. Frost JA, Geppert TD, Cobb MH, Feramisco JR. (1994) A requirement for extracellular signal-regulated kinase (ERK) function in the activation of AP-1 by Ha-Ras, phorbol 12-myristate 13-acetate, and serum. Proc. Natl. Acad. Sci. U.S.A 91: 3844-3848.

45. Reunanen N, Westermarck J, Hakkinen L, et al. (1998) Enhancement of fibroblast collagenase (matrix metalloproteinase-1) gene expression by ceramide is mediated by extracellular signal-regulated and stress-activated protein kinase pathways. J. Biol. Chem. 273: 5137-5145.

46. Westermarck J, Holmstrom T, Ahonen M, Eriksson JE, Kahari VM. (1998) Enhancement of fibroblast collagenase-1 (MMP-1) gene expression by tumor promoter okadaic acid is mediated by stress-activated protein kinases Jun $\mathrm{N}$-terminal kinase and p38. Matrix Biol. 17: 547-557.

47. Hofmann MA, Drury S, Fu C, et al. (1999) RAGE mediates a novel proinflammatory axis: a central cell surface receptor for S100/calgranulin polypeptides. Cell 97: 889-901.

48. Yokoo T, Kitamura M. (1996) Dual regulation of IL-1 beta-mediated matrix metalloproteinase-9 expression in mesangial cells by NF-kappa B and AP-1. Am. J. Physiol. 270: F123-F130.

49. Rippe RA, Schrum LW, Stefanovic B, Solis-Herruzo JA Brenner DA. (1999) NF-kappaB inhibits expression of the alphal(I) collagen gene. DNA Cell Biol. 18: 751-761.

50. Woessner JF Jr. (1999) Matrix metalloproteinase inhibition. From the Jurassic to the third millennium. Ann. N.Y. Acad. Sci. 878: $388-403$.

51. Tyagi SC, Kumar S, Voelker DJ, Reddy HK, Janicki JS, Curtis JJ. (1996) Differential gene expression of extracellular matrix components in dilated cardiomyopathy. J. Cell. Biochem. 63: 185-198.

52. Power WJ, Kaufman AH, Merayo-Lloves J, ArrunateguiCorrea V, Foster CS. (1995) Expression of collagens I, III, IV and $\mathrm{V}$ mRNA in excimer wounded rat cornea: analysis by semi-quantitative PCR. Curr. Eye Res. 14: 879-886.

53. Kanwar YS, Liu ZZ, Kumar A, Usman MI, Wada J, Wallner EI. (1996) D-glucose-induced dysmorphogenesis of embryonic kidney. J. Clin. Invest. 98: 2478-2488.

54. Roy S, Lorenzi M. (1996) Early biosynthetic changes in the diabetic-like retinopathy of galactose-fed rats. Diabetologia 39 735-738.

55. Barasch J, Yang J, Qiao J, et al. (1999) Tissue inhibitor of metalloproteinase-2 stimulates mesenchymal growth and regulates epithelial branching during morphogenesis of the rat metanephros. J. Clin. Invest. 103: 1299-1307.

56. Lemstrom KB, Aho PT, Bruggeman CA, Hayry PJ. (1994) Cytomegalovirus infection enhances mRNA expression of platelet-derived growth factor-BB and transforming growth factor-beta 1 in rat aortic allografts. Possible mechanism for cytomegalovirus-enhanced graft arteriosclerosis. Arterioscler. Thromb. 14): 2043-2052. 